\title{
Corporate Social Responsibility of a Fair Trade Company: A Cross-Country Study of Taiwanese and American Business Students' Perceptions
}

\author{
Mei-Hua Chen ${ }^{1} \&$ Bryan H. Chen ${ }^{1}$ \\ ${ }^{1}$ Department of Finance, National Changhua University of Education, Taiwan \\ Correspondence: Bryan H. Chen, National Changhua University of Education, Changhua City, Taiwan. E-mail: \\ hhchen@cc.ncue.edu.tw
}

Received: April 20, 2018

doi:10.5539/ijbm.v13n7p69
Accepted: May 6, 2018

Online Published: June 15, 2018

URL: https://doi.org/10.5539/ijbm.v13n7p69

\begin{abstract}
This study investigated and compared Taiwanese and American business students' perceptions of the corporate social responsibility (CSR) of a fair trade (FT) company. A total of 402 and 470 questionnaires were collected in United States and Taiwan, respectively, of which 384 and 432 were usable, respectively. Nationality, gender, work experience, and religion were the four variables that affected the participants' understanding of an FT company's CSR in this study. The findings of this study have implications for business school curricula in Taiwan and the United States and provide useful ideas for enhancing social responsibility in business schools.
\end{abstract}

Keywords: corporate social responsibility, fair trade, corporate social responsibility education, business student

\section{Introduction}

\subsection{Corporate Social Responsibility in Business Education}

Although corporate social responsibility (CSR) has been studied extensively (Cacioppe, Forster, \& Fox, 2008), business education remains overly focused on financial concerns (Giacalone \& Thompson, 2006). Elias (2004) highlighted that the increasing attention given to CSR has led to more studies recruiting business students as participants. Many researchers believe that providing CSR education in universities is crucial because business education is essential for students' moral and ethical development (Gaa \& Thorne, 2004; Bampton \& Maclagan, 2005; Block \& Cwik, 2007). Wood (2007) discovered that few studies have discussed an individual-level perspective regarding CSR. If business schools can invest in developing faculty research and proactive CSR education, they can also promote CSR awareness among stakeholders (Cornelius, Wallace, \& Tassabehji, 2007).

Paul and Hall (1995) analyzed the influence of integrating CSR in the business curriculum. Gordon (1998) indicated that students can become aware of a corporation's social responsibility through extensive class discussion. Brown (1994) suggested that students can be cast in various stakeholder roles. Muijen (2004) believed that CSR as value education should be part of higher education. Gardiner and Lacy (2005, p. 174) mentioned that business strategist Michael Porter urges the need for the "right types and quality of education of future employees" as requirement for a business to invest successfully in CSR. Su (2006) indicated that the ethics of decision-making processes are expected to have considerable personal influence. CSR orientation is of particular interest to CSR researchers (Ibrahim, Angelidis, \& Howard, 2006). Hamann, van Duin, Appels, Taylor, and Akor (2006) investigated the extent to and manner in which CSR-related topics are taught to business students. The top business schools accredited by the Association to Advance Collegiate Schools of Business often offer proactive CSR education, with the lower tier usually offering a more reactive CSR education (Cornelius et al., 2007). Co'rdoba and Campbell (2008) utilized systems thinking to develop business students' awareness of CSR and related intervention skills and to enhance their future engagement with CSR.

Nicholson and DeMoss (2009) revealed that all department coordinators in a sample expressed that coverage of social responsibility in their curricula was inadequate. Gray (2010) argued that university education should not only develop students' academic and social skills but also cultivate their moral, spiritual, and religious life dimensions. Maclagan and Campbell (2011) argued that faculties must retain focus on students' individual actions and moral judgments when teaching CSR-related topics. Jorge and Peña (2014) discussed studies related to CSR education in business school (MacFarlane \& Ottewill, 2004; Özdemir \& Sarikaya, 2009; Fernández \& 
Bajo, 2010; Rundle-Thiele \& Wymer, 2010; Ceulemans, De Prins, Cappuyns, \& Coninck, 2011; Setó-Pamies, Domingo-Vernis, \& Rabassa-Figueras, 2011). CSR education related to ethics knowledge and societal values (Memon, Bhutto, Chanar, \& Robson, 2015).

\subsection{CSR Strategies}

Most businesses today embrace CSR because people strongly support and require CSR campaigns (Carroll \& Shabana, 2010). The role of a corporation is to serve the public's best interests, including non-investing stakeholders and investing shareholders (Jensen, 2002; Calton \& Payne, 2003; Jo \& Harjoto, 2011; Sul, Choi, \& Quan, 2014). Corporations embrace CSR to relieve social, environmental, and economic problems with a view to increasing public and stakeholder benefits (González-Rodríguez, Díaz-Fernández, Pawlak, \& Simonetti, 2012), as well as achieving sustainable development (Coppa \& Sriramesh, 2013). A CSR campaign should constitute an interrelationship to reflect social imperatives and business success as opposed to a zero-sum game (Murphy \& Schlegelmilch, 2013). Hilson (2012) mentioned that consumers increasingly prefer products and services offered by socially responsible companies. Yu and Choi (2014) revealed that stakeholders may push companies to form a well-established CSR-oriented culture. Better CSR practices can improve society (Lam, 2014). Palihawadana, Oghazi, and Liu (2016) indicated that CSR is increasingly vital in business and academia.

When corporations face competition in the real world, they must develop CSR within the limits of economic reality and commercial feasibility. Although translating CSR policies into concrete activities requires new frameworks and enforcement of new solutions, FT may offset the conflict between profit and CSR.

\subsection{CSR and FT}

FT and CSR are prime examples of social responsibility in consumer society (Castaldo, Perrini, Misani, \& Tencati, 2009). Moore, Slack, and Gibbon (2009) agreed that FT is a great example of responsible business practice. FT promotes an ethical vision that enables businesses to profit by operating in developing countries and can help to combat poverty (Blowfield \& Dolan, 2010).

Friedman (1962) noted that businesses must focus on maximizing profits for shareholders; however, this view has shifted because businesses are part of society and have a responsibility toward the greater good (Donaldson \& Werhane, 1996; Joyner \& Payne, 2002). Elkington (2002) emphasized that the concept of CSR is similar to the Triple P (people, planet, and profit) concept. The European Free Trade Association (2002, p. 24) described FT as "trading partnership based on dialogue, transparency, and respect that seeks greater equity in international trade. It contributes to sustainable development by offering better trading conditions to, and securing the rights of, marginalized producers and workers - especially in the South.”

Through dialogue, companies can know where the products they purchase originate from and how they are produced. Therefore, companies take responsibility for sourcing and produce products to be transparent and accountable; this can enhance customers' purchase intentions and can meet sustainability goals and profit needs. Conscious consumers are usually attracted by FT products (Taylor, 2005). FT has three functions: to terminate poverty, empower producers and workers to enhance their social capital, and assist global trade reform (Nicholls \& Opal, 2005). Randall (2005) revealed that if businesses maintain ethical standards, they acquire advantages from consumers' increasing social and ethical interests.

Low and Davenport (2006) mentioned that FT is becoming a complex ethical consumer movement demanding socially and environmentally sustainable production processes. Barnett (2007) urged that responsible consumption can be a useful tool to compel producers to incorporate social responsibility strategies. Mann (2008) called these FT goods "moral goods." Mohan (2009) noted that FT reminds consumers to make economic decisions to alter the social and ethical effects of other stakeholders on producers and workers. Small and medium-sized enterprises' FT engagement in CSR differs from that of larger companies (Davies \& Crane, 2010). Witkowski and Reddy (2010) indicated that few studies on FT have been conducted in the United States. Consequently, Boluk (2013) suggested that exploration to gain understanding of FT and CSR practices is necessary in future studies.

\subsection{The Purposes of Study}

Despite growing interest in CSR education, CSR has been investigated only studies in Western countries (Ng \& Burke, 2010; Kolodinsky, Madden, Zisk, \& Henkel, 2010). Meanwhile, FT has received increasing academic interest (Davies \& Ryals, 2010). Memon, Wei, Robson, and Khattak (2014) revealed that in developing countries, CSR is incorporated into business curricula to a limited extent. CSR should consider the interests of stakeholders, and business schools are an example of this. Therefore, the relationship between business schools and firms is crucial (Tari, 2011; Gawel, 2014). 
To create a suitable CSR education program, students' backgrounds and prior knowledge must be revealed to help educators target the specific weaknesses of CSR and ascertain whether misconceptions exist. Educators would then know how to bridge the gap between prior knowledge and new learning materials (Cook, 2014).

Currently, no model for CSR education is available in Taiwan for business schools to follow. With its advanced development of CSR and FT, the Western world may provide a suitable example for higher education in Taiwan. Cultures with different ethical values may generate different perceptions of CSR practice and FT. Even when studying CSR education experiences in the United States, we must pay attention to cultural differences. Tsakumis (2007) indicated that national cultural dimensions explain general similarities and differences among societies worldwide. CSR is evidently culture bound (Jamali \& Mirshak, 2007; Ringov \& Zollo, 2007). Azmat (2010) noted that cultural effects on individuals' ethical and moral perspectives lead to contrasting corporate practices.

Sohn, Han, and Lee (2012) suggested that CSR practices are increasingly common worldwide. Most studies on CSR have focused on the context of developed countries as opposed to that of developing countries (Denni \& Lasmono, 2010; Pham, 2011); however, CSR seems more critical for developing countries (Khan, Lew, \& Park, 2015). Lund-Thomsen, Lindgreen, and Vanhamme (2016) illustrated that this research gap was due to companies in developing countries more readily engaging in socially irresponsible behavior. The present study aimed to fill this research gap by examining how business students perceive CSR in FT companies in a developing and developed countries.

Shaw and Clarke (1999) illustrated that religion has a positive normative influence on FT. Witkowski (2005) indicated that patronage of an FT company may be positively associated with religiosity. Religious respondents may report more ethical consumption activities than their nonreligious counterparts.

This study investigated and compared Taiwanese and American business students' perceptions of the CSR of an FT company. The following research questions were formulated to guide this study. (1) To what extent do business students understand the CSR perceptions of an FT company? (2) What are the differences in business students' understanding of the CSR perceptions of an FT company based on the demographic factors of nationality, full-time work experience, gender, and religion?

\section{Methodology}

A questionnaire was designed as a research instrument to investigate and compare Taiwanese and American business students' perceptions of the CSR of an FT company. The survey questionnaire was created based on research on the CSR perceptions of an FT company. The CSR questionnaire was based on the well-known Carroll's framework, which has philanthropic, economic, legal, and ethical components. The questionnaire draft was translated into Chinese and modified to fit the present study. Subsequently, three experienced scholars from the academic CSR field were invited to examine the questionnaire. The scholars were requested to evaluate the clarity of wording, rhetoric, and alteration of items. The expert panel assessed the questionnaire and offered detailed feedback as well as modifications of items for the study to achieve content validity. Subsequently, a pretest was conducted. Perneger, Courvoisier, Hudelson, and Gayet-Ageron (2015) recommended 30 participants as a pretest sample size in a psychometric questionnaire. Pretest data was collected from 30 business students to examine the reliability of the questionnaire. The final formal survey questionnaire was adjusted based on the pretest results.

Because of the difficulty of collecting responses, purposive sampling was implemented in this study. Briggs and Coleman (2007) defined purposive or judgmental sampling as an improvement approach where researchers apply their experience to select what is most representative or typical of the population. Data was collected by conducting a survey of 500 business students in Taiwan and the United States. Selected students were issued the survey with a cover letter requesting participation in this research attached as the front page. The survey was completed anonymously in class.

A 5-point Likert scale was used to identify participants' attitudes toward the CSR perceptions of an FT company. This study also examined differences in perceptions based on students' personal characteristics such as nationality, full-time work experience, gender, and religion. Descriptive statistics, $t$ tests, and a one-way analysis of variance with a 0.05 level of significance were utilized for data analyses. Statistical analysis was conducted using SPSS version 21.0.

\section{Results}

\subsection{Descriptive Statistics}

A total of 402 questionnaires were collected in the United States, of which 384 were usable; the effective rate 
was $96 \%$. A total of 470 questionnaires were collected in Taiwan, of which 432 were usable; the effective rate was $92 \%$. These questionnaires were used in the data analyses. The sample is characterized in Table 1.

Table 1. Participant demographics data descriptive statistics

\begin{tabular}{llll}
\hline & US $(\mathrm{n}=384,47.1 \%)$ & Taiwan $(\mathrm{n}=432,52.9 \%)$ & Total $(\mathrm{n}=816,100 \%)$ \\
\hline Work experience (\%) & & & \\
Yes & 85.7 & 78.5 & 18.9 \\
No & 14.3 & 21.5 & \\
Gender (\%) & & & 53.4 \\
Female & 44.8 & 61.1 & 45.2 \\
Male & 54.4 & 37.0 & 1.4 \\
Others & 0.8 & 1.9 & 38.1 \\
Religion (\%) & & & 61.9 \\
Yes & 53.6 & 24.3 & \\
No & 46.4 & 75.7 & \\
\hline
\end{tabular}

Most of the participants (more than 3/4) had work experience in Taiwan and the United States. More than half of the participants in Taiwan (61.1\%) were female, whereas less than half were female in the United States (44.8\%). Regarding religion, more than half of the participants in the United States $(53.6 \%)$ were religious, whereas approximately one quarter of the participants in Taiwan $(24.3 \%)$ were religious.

\subsection{Reliability of Measures}

The questionnaire was developed to understand the CSR perceptions of an FT company. To perform a cross-national comparison, the same items needed to be used for the United States and Taiwan. For factor analysis, ten items were divided into two factor types, namely philanthropic and ethical (PE) factors and economic and legal (EL) factors, and were measured based on five items. The reliability value (Cronbach's alpha) for each sub-factor was calculated for the whole sample and demonstrated acceptable results (PE: 0.700, EL: 0.773). For the US sample, the reliability values were 0.672 for PE and 0.756 for EL. For the Taiwanese sample, the corresponding values were 0.739 for PE and 0.790 for EL. The results of the reliability test and factor analysis are shown in Table 2.

Table 2. The results of factor analysis

\begin{tabular}{|c|c|c|c|}
\hline Items & US & TW & WHOLE \\
\hline \multicolumn{4}{|l|}{ Philanthropic \& Ethics (PE) Cronbach's alpha US=.672, TW=.739, Whole $=.700$} \\
\hline 1. Allow your employees to volunteer to help in the shelter & .742 & .731 & .724 \\
\hline 2. Financial contribute annually & .779 & .795 & .784 \\
\hline 3. Solve social problems in the community. & .780 & .720 & .750 \\
\hline 8. Voluntarily \& immediately recall (costly) and fix the products for potential safety issue. & .330 & .446 & .383 \\
\hline $\begin{array}{l}\text { 10. Primary goal of a fair trade company should be providing cultural, social, and economic } \\
\text { benefits. }\end{array}$ & .574 & .777 & .680 \\
\hline \multirow{2}{*}{\multicolumn{4}{|c|}{$\begin{array}{l}\text { Economic \& Legal (EL) Cronbach's alpha US=.756, TW=.790, } \\
\text { Whole }=.773\end{array}$}} \\
\hline & & & \\
\hline 4. Move manufacturing plants overseas to maintain competitiveness and profitability. & 691 & 678 & 679 \\
\hline 5. The only social responsibility of a fair trade company is economic concern. & 635 & 677 & .654 \\
\hline 6. Terminate legal obligation for helping business associate. & .750 & .653 & .709 \\
\hline 7. Lower the standard of air pollution level for gaining competitiveness. & .765 & .847 & .812 \\
\hline 9. Allow bribe for specific purpose. & .712 & .794 & .749 \\
\hline
\end{tabular}

Factor Analysis: US: Kaiser-Meyer-Olkin value=.753, Bartlett's test Sig=.000, Cumulative \%: 47.935\% TW: Kaiser-Meyer-Olkin value=.787, Bartlett's test Sig=.000, Cumulative \%: $53.337 \%$ Whole sample: Kaiser-Meyer-Olkin value=.782, Bartlett's Sig=.000, Cumulative \%: 49.950\%

The mean values for the CSR perceptions of an FT company were 3.47 (standard deviation [SD] $=.52$ ) in the United States and $3.43(\mathrm{SD}=.47)$ in Taiwan. The mean values for PE factors were $3.91(\mathrm{SD}=.67)$ in the United States and $3.96(\mathrm{SD}=.59)$ in Taiwan. The mean values for EL factors were $3.04(\mathrm{SD}=.85)$ in the United States 
and $2.90(\mathrm{SD}=.83)$ in Taiwan. The Taiwanese participants had a higher mean score for PE factors than did the US participants; however, the US participants had a higher mean score for EL factors than did the Taiwanese participants. Overall, the US participants had a higher mean score for "the CSR perceptions of an FT company" than did the Taiwanese participants. These statistics are characterized in Table 3.

Table 3. CSR of a Fair trade company between US and Taiwan differences analyses

\begin{tabular}{|c|c|c|c|c|c|}
\hline \multirow{2}{*}{ Item } & \multicolumn{2}{|c|}{ US (n=384) } & \multicolumn{2}{|c|}{$\mathrm{TW}(\mathrm{n}=432)$} & \multirow{2}{*}{ t-value $(P)$} \\
\hline & Mean & SD & Mean & SD & \\
\hline Philanthropic \& Ethics (PE) & 3.905 & 0.667 & 3.959 & 0.587 & $-1.222(.222)$ \\
\hline $\begin{array}{l}\text { 1. Allow your employees to volunteer to help in } \\
\text { the shelter }\end{array}$ & 4.016 & 1.050 & 3.900 & 0.865 & $1.689(.090)^{*}$ \\
\hline 2. Financial contribute annually & 3.820 & 1.104 & 3.942 & 0.814 & $-1.776(.076)^{*}$ \\
\hline 3. Solve social problems in the community. & 3.724 & 1.048 & 4.019 & 0.812 & $-4.448(.000)^{* * *}$ \\
\hline $\begin{array}{l}\text { 8. Voluntarily \& immediately recall (costly) and } \\
\text { fix the products for potential safety issue. }\end{array}$ & 3.964 & 0.950 & 3.852 & 0.912 & $1.712(.087)^{*}$ \\
\hline $\begin{array}{l}\text { 10. Primary goal of a fair trade company should } \\
\text { be providing cultural, social, and economic } \\
\text { benefits. }\end{array}$ & 4.003 & 0.901 & 4.083 & 0.709 & $-1.353(.176)$ \\
\hline Economic \& Legal (EL) & 3.040 & 0.846 & 2.901 & 0.829 & $2.375(.018)^{* *}$ \\
\hline $\begin{array}{l}\text { 4. Move manufacturing plants overseas to } \\
\text { maintain competitiveness and profitability. }\end{array}$ & 3.018 & 1.191 & 2.625 & 0.962 & $5.148(.000)^{* * *}$ \\
\hline $\begin{array}{l}\text { 5. The only social responsibility of a fair trade } \\
\text { company is economic concern. }\end{array}$ & 2.802 & 1.135 & 2.600 & 1.037 & $2.664(.008)^{* * *}$ \\
\hline $\begin{array}{l}\text { 6. Terminate legal obligation for helping } \\
\text { business associate. }\end{array}$ & 3.251 & 1.187 & 3.137 & 1.112 & $1.413(.158)$ \\
\hline $\begin{array}{l}\text { 7. Lower the standard of air pollution level for } \\
\text { gaining competitiveness. }\end{array}$ & 3.219 & 1.169 & 3.097 & 1.220 & $1.448(.148)$ \\
\hline 9. Allow bribe for specific purpose. & 2.912 & 1.257 & 3.046 & 1.263 & $-1.526(.127)$ \\
\hline Total Average & 3.473 & 0.523 & 3.430 & 0.467 & $1.230(.219)$ \\
\hline
\end{tabular}

\subsection{Inferential Statistics}

Significant differences existed regarding American business students' understanding of the CSR perceptions of an FT company based on work experience. The participants with work experience had a more positive attitude at a $1 \%$ significance level than did those without work experience in the United States. In addition, significant differences existed regarding Taiwanese participants' understanding of the CSR perceptions of an FT company based on work experience. The participants with work experience had a more positive attitude at a $10 \%$ significance level than did those without work experience in Taiwan. Overall, significant differences existed regarding all business students' understanding of the CSR perceptions of an FT company based on work experience. The participants with work experience had a more positive attitude at a $1 \%$ significance level than did those without work experience. These statistics are characterized in Table 4.

Table 4. CSR perception differences analysis based on Participants' Work Experience

\begin{tabular}{|c|c|c|c|c|c|c|c|c|c|c|}
\hline \multirow{2}{*}{ Factor } & \multirow{2}{*}{$\begin{array}{l}\text { Work } \\
\text { Experience }\end{array}$} & \multicolumn{3}{|l|}{ US } & \multicolumn{3}{|l|}{ TW } & \multicolumn{3}{|c|}{ Whole Sample } \\
\hline & & $\mathrm{M}$ & SD & t-value & $\mathrm{M}$ & SD & t-value & $\mathrm{M}$ & SD & t-value \\
\hline \multirow{2}{*}{ PE } & yes & 3.888 & 0.670 & -1.228 & 3.982 & 0.593 & 1.560 & 3.936 & 0.633 & 0.204 \\
\hline & no & 4.007 & 0.644 & $(.220)$ & 3.875 & 0.561 & $(.120)$ & 3.924 & 0.595 & $(.838)$ \\
\hline \multirow{2}{*}{ EL } & yes & 3.119 & 0.810 & $4.599 * * *$ & 2.919 & 0.829 & 0.874 & 3.018 & 0.825 & $3.737 * * *$ \\
\hline & no & 2.567 & 0.905 & $(.000)$ & 2.834 & 0.829 & $(.383)$ & 2.735 & 0.865 & $(.000)$ \\
\hline \multirow{2}{*}{ Total } & yes & 3.504 & 0.530 & $2.865 * * *$ & 3.451 & 0.458 & $1.760 *$ & 3.477 & 0.495 & $3.295 * * *$ \\
\hline & no & 3.287 & 0.443 & $(.004)$ & 3.355 & 0.494 & $(.079)$ & 3.330 & 0.475 & $(.001)$ \\
\hline
\end{tabular}

US: $\mathrm{N}$ for participants with work experience $=329$, without work experience $=55$,

TW: $\mathrm{N}$ for participants with work experience $=339$, without work experience $=93$,

Whole Sample: $\mathrm{N}$ for participants with work experience $=668$, without work experience $=148$, 
Significant differences existed regarding American and Taiwanese business students' understanding of the CSR perceptions of an FT company based on gender. The female participants had a more positive attitude at a $1 \%$ significance level than did the male participants in the United States and Taiwan. Overall, significant differences existed regarding all business students' understanding of the CSR perceptions of an FT company based on gender. Furthermore, the female participants had a more positive attitude at a $1 \%$ significance level than did the male participants. These statistics are characterized in Table 5.

Table 5. CSR perceptions differences analyses based on participants gender

\begin{tabular}{|c|c|c|c|c|c|c|c|c|c|c|}
\hline \multirow{2}{*}{ Factor } & \multirow{2}{*}{ Gender } & \multicolumn{3}{|l|}{ US } & \multicolumn{3}{|l|}{ TW } & \multicolumn{3}{|c|}{ Whole Sample } \\
\hline & & M & SD & t-value & M & SD & t-value & M & SD & t-value \\
\hline \multirow{2}{*}{ PE } & Female & 4.053 & 0.616 & $3.909 * * *$ & 3.996 & 0.516 & 1.433 & 4.015 & 0.558 & $4.023 * * *$ \\
\hline & Male & 3.782 & 0.685 & $(.000)$ & 3.905 & 0.690 & $(.153)$ & 3.835 & 0.689 & $(.000)$ \\
\hline \multirow{2}{*}{ EL } & Female & 3.259 & 0.842 & $4.772 * * *$ & 3.000 & 0.805 & $2.890 * * *$ & 3.103 & 0.829 & $4.917 * * *$ \\
\hline & Male & 2.855 & 0.807 & $(.000)$ & 2.763 & 0.852 & $(.004)$ & 2.815 & 0.827 & $(.000)$ \\
\hline \multirow{2}{*}{ Total } & Female & 3.652 & 0.500 & $6.526 * * *$ & 3.498 & 0.460 & $3.549 * * *$ & 3.559 & 0.482 & $6.866 * * *$ \\
\hline & Male & 3.318 & 0.495 & $(.000)$ & 3.334 & 0.465 & $(.000)$ & 3.325 & 0.482 & $(.000)$ \\
\hline
\end{tabular}

US: $\mathrm{N}$ for Female=172, Male=209, TW: $\mathrm{N}$ for Female=264, Male=160, Whole sample: $\mathrm{N}$ for Female=436, Male=369.

No significant differences regarding American business students' understanding of the CSR perceptions of an FT company based on religion were observed. However, significant differences existed regarding Taiwanese participants' understanding of the CSR perceptions of an FT company based on religion. Religious participants had a more positive attitude at a $10 \%$ significance level than did nonreligious participants in Taiwan. Overall, significant differences existed regarding all business students' understanding of the CSR perceptions of an FT company based on religion. Religious participants had a more positive attitude at a $10 \%$ significance level than did nonreligious participants. These statistics are characterized in Table 6 .

Table 6. CSR perceptions differences analyses based on participants' religion

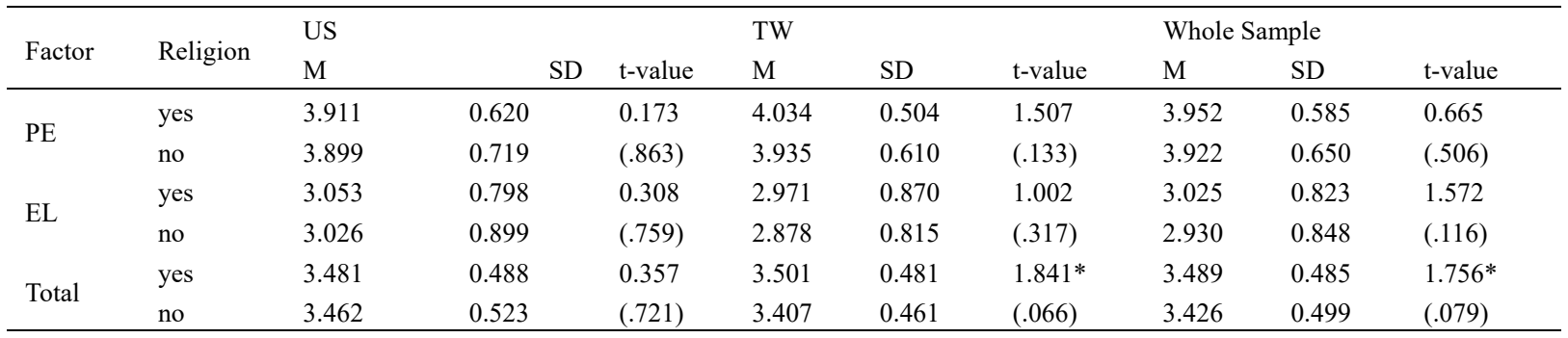

US: $\mathrm{N}$ for participant with religion=206, without religion $=178$, TW: $\mathrm{N}$ for participant with religion=105, without religion=327, Whole sample: $\mathrm{N}$ for participant with religion $=311$, without religion $=505$.

\section{Discussion}

\subsection{Major Findings and Implications}

This study investigated and compared Taiwanese and American business students' perceptions of the CSR of an FT company. Most business students had taken the business ethics course and understood the issue of ethical

judgment. They have knowledge to identify unethical behavior. Bregman, Peng, \& Chin (2015) indicated a strong relationship between consumers' ethical judgment and their purchasing intention of firm's products. Liu, Yang, Zeng, \& Waller (2015) did the unethical consumer behavior research in China, and found out that unethical consumer behavior for consumers deeply combined with quanxi-oriented social culture, which is different from Western consumers. CSR gains increasing attention and interest worldwide. Although CSR is developing, translating CSR policies into concrete activities requires new frameworks and enforcement of new solutions. FT may offset the conflict between profit and CSR. Dialogue between faculties and students is a fundamental means of shifting businesses toward more socially responsible practices. CSR education refers to teaching and researching CSR. Faculty attitudes regarding the CSR perceptions of an FT company may influence students' awareness and enhance their understanding of the CSR of an FT company. In conclusion, the four 
variables of nationality, gender, work experience, and religion affected the participants' understanding of the CSR perceptions of an FT company in this study.

\subsection{Limitations and Suggestions for Future Studies}

Although this study provided answers to questions regarding the CSR perceptions of an FT company, it had a limitation in that it used a purposive sample of Taiwanese and American business students. Because FT is one of the most noteworthy sectors of ethical consumerism worldwide, it should serve as a suitable topic for investigating FT attitudes and FT behaviors among Taiwanese and American business students. Many conscientious consumers insist on making their economic decisions based on ethical values. When consumers aware that business contributed to the society, consumers' purchase attitudes and behaviors were increased.

\section{Acknowledgments}

Financial support provided by the Ministry of Science and Technology of Taiwan (Grant No.: Taiwan [MOST 106-2918-I-018 -004) is gratefully acknowledged.

\section{References}

Azmat, F. (2010). Exploring social responsibility of immigrant entrepreneurs: Do home country contextual factors play a role? European Management Journal, 28, 377-386. https://doi.org/10.1016/j.emj.2009.11.004

Arlow, P. (1991). Personal characteristics in college students' evaluations of business ethics and corporate social responsibility. Journal of Business Ethics, 10, 63-69. https://doi.org/10.1007 / BF00383694

Bampton, R., \& Maclagan, P. (2005). Why teach ethics to accounting students? A response to the sceptics. Business Ethics: A European Review, 14(3), 290-300. https://doi.org/10.1111 / j.1467-8608.2005.00410.x

Barnett, M. (2007). Stakeholder influence capacity and the variability of financial returns to corporate social responsibility. Academy of Management Review, 32(3), 794-816. https://doi.org/10.5465/AMR.2007.25275520

Block, W., \& Cwik, P. F. (2007). Teaching business ethics: A classificationist approach. Business Ethics: A European Review, 16(2), 98-106. https://doi.org/10.1111/j.1467-8608.2007.00480.x

Blowfield, M. E., \& Dolan, C. (2010). Fairtrade facts and fancies: What Kenyan Fairtrade tea tells us about business' role as development agent. Journal of Business Ethics, 93,143-162. https://doi.org/10.1007/s10551-010-0558-2

Boluk, K. (2013). Using CSR as a tool for development: An investigation of the Fair Hotels scheme in Ireland. Journal of Quality Assurance in Hospitality \& Tourism, 14, 49-65. https://doi.org/10.1080/1528008X.2013.749382

Bregman, R., Peng, D. X., \& Chin, W. (2015). The effect of controversial global sourcing practices on the ethical judgments and intentions of U.S. consumers. Journal of Operations Management, 36229-243. https://doi.org/10.1016/j.jom.2015.01.001

Briggs, A. R. J., \& Coleman, M. (Eds.). (2007). Research methods in educational leadership and management. Los Angeles: SAGE Publications. https://doi.org/10.4135 / $9781473957695 . n 14$

Brown, K. M. (1994). Using role play to integrate ethics into the business curriculum: A financial management example. Journal of Business Ethics, 13(2), 105-110. https://doi.org/10.1007/BF00881579

Cacioppe, R., Forster, N., \& Fox, M. (2008). A survey of managers' perception of corporate ethics and social responsibility and actions that may affect companies' success. Journal of Business Ethics, 82, 681-700. https://doi.org/10.1007 / s10551-007-9586-Y

Calton, J. M., \& Payne, S. L. (2003). Coping with paradox: Multistakeholder learning dialogue as a pluralist sense making process for addressing messy problems. Business and Society, 42(1), 7-42. https://doi.org/10.1177/0007650302250505

Carroll, A. B., \& Shabana, K. M. (2010). The business case for corporate social responsibility: A review ofconcepts, research and practice. International Journal of Management Review, 12(1), 85-105. https://doi.org/10.1111 / j.1468-2370.2009.00275.x

Castaldo, S., Perrini, F., Misani, N., \& Tencati, A. (2009). The missing link between corporate social responsibility and consumer trust: The case of Fair Trade products. Journal of Business Ethics, 84, 1-15. https://doi.org/10.1007 / s10551-008-9669-4

Ceulemans, K., De Prins, M., Cappuyns, D., \& Coninck, W. (2011). Integration of sustainable development in 
higher education's curricula of applied economics: large scale assessments, integration strategies and barriers. Journal of Management and Organization, 17(5), 621-640. https://doi.org/10.5172/jmo.2011.17.5.621

Cook, P. R. (Eds.). (2014 ). Educational Trends: A Symposium in Belize, Central American. Cambridge Scholars Publishing, 1st Unabridged edition. https://doi.org/10.7202/1028707ar

Coppa, M., \& Sriramesh, K. (2013). Corporate social responsibility among SMEs in Italy. Public Relations Review, 39(1), 30-39. https://doi.org/10.1002/sres.899

Co'rdoba, J. R., \& Campbell, T. (2008). Learning to deal with CSR issues in the classroom. Systems Research and Behavioral Science, 25, 427-437. DOI:10.1002/sres.898

Cornelius, N., Wallace, J., \& Tassabehji, R. (2007). An analysis of corporate social responsibility, corporate identity and ethics teaching in business schools. Journal of Business Ethics, 76, 117-135. https://doi.org/10.1007/s10551-006-9271-6

Davies, I. A., \& Ryals, L. J. (2010). The role of social capital in the success of fair trade. Journal of Business Ethics, 96, 317-338. https://doi.org/10.1007/s10551-010-0468-3

De Mooij, M., \& Hofstede, G., (2010). The Hofstede model: Applications to global branding and advertising strategy and research. International Journal of Advertising 29(1), 85-110. https://doi.org/10.2501/S026504870920104X

Denni, I. A., \& Lasmono, H. K. (2010). Consumers' perception of corporate social responsibility in a developing country. International Journal of Consumer Studies, 34(1), 46-51. https://doi.org/10.1111/j.1470-6431.2009.00824.x

Doh, J. P., \& Tashman, P. (2014). Half a world away: The integration and assimilation of a corporate social responsibility, substantially, and sustainable development in business school curricula. Corporate Social Responsibility and Environmental Management, 21, 131-142. https://doi.org/10.1002 / csr.1315

Donaldson, T., \& Werhane, P. H. (1996). Ethical Issues in Business: A Philosophical Approach, 5th Edition. Prentice Hall, Upper Saddle River, NJ. https://doi.org/10.1016 / S0737-6782(96)80018-X

Elias, R. Z. (2004). An examination of business students' perceptions of corporate social responsibilities before and after Bankruptcies. Journal of Business Ethics, 52, 267-281. https://doi.org/10.1023/B:BUSI.0000037558.74693.d5

Elkington, J. (2002). Cannibals with forks. The Triple Bottom Line of 21 st Century Business. Capstone, Oxford. https://doi.org/10.1002/tqem.3310080106

Fernández, J. L., \& Bajo, A. (2010). The presence of business ethics and CSR in higher education curricula for executives: the case of Spain'. Journal of Business Ethics Education, 7, 25-38. https://doi.org/10.5840/jbee20131010

Friedman, M. (1962). Capitalism and Freedom. The University of Chicago Press, Chicago, IL. https://doi.org/10.7208/chicago/9780226264189.001.0001

European Fair Trade Association. (2002). EFTA Yearbook: Challenges of Fair Trade 2001-2003 (EFTA, Maastricht, Netherlands). https://doi.org/10.1007/978-1-349-59051-3_14

Gaa, J. C., \& Thorne, L. (2004). An introduction to special issue on professionalism and ethics in accounting education. Issue in Accounting Education, 19(1), 1-6. https://doi.org/10.1016/B978-0-08-042405-7.50058-7

Gardiner, L., \& Lacy, P. (2005). Lead, respond, partner or ignore: the role of business schools on corporate responsibility. Corporate Governance, 5, 174-185. https://doi.org/10.1108/14720700510562749

Gawel, A. (2014) Business collaboration with universities as an example of corporate social responsibility: A review of case study collaboration methods. Poznań University of Economics Review, 14(1), 20-30. https://doi.org/10.1111/basr.12028

Giacalone, R. A., \& Thompson, K. (2006). Business ethic and social responsibility education: Shifting the worldview. Academy of Management and Learning Education, 5(3), 266-277. https://doi.org/10.1007/s11135-012-9781-5

González-Rodríguez, M. R., Díaz-Fernández, M. C., Pawlak, M., \& Simonetti, B. (2012). Perceptions of students university of corporate social responsibility. Quality \& Quantity, 47(4), 2361-2377. https://doi.org/10.1007/s11135-012-9781-5 
Gordon, I. M. (1998). Enhancing students' knowledge of social responsibility accounting. Issue in Accounting Education, 13, 31-46. https://doi.org/10.1506/HWBX-FWFU-QTMC-XQLC

Gray, B. (2010). The rise of voluntary work in higher education and corporate social responsibility in business: Perspectives of students and graduate employees. Journal of Academic Ethics, 8, 95-109. https://doi.org/10.1007/s10805-010-9105-0

Hamann, R., Van Duin, L., Appels, C., Taylor, E., \& Akor, E. (2006). Corporate citizenship in South African business education. South African Business Management, 37(2), 45-53. https://doi.org/10.4314/sajhe.v17i2.25308

Hilson, G. (2012). Corporate social responsibility in the extractive industries: experiences from developing countries. Resource Policy, 37(2), 131-137. https://doi.org/10.1016/ j.resourpol.2012.01.002

Ibrahim, N. A., Angelidis, J. P., \& Howard, D. P. (2006). Corporate social responsibility: A comparative analysis of perceptions of practicing accountants and accounting students. Journal of Business Ethics, 66, 157-167. https://doi.org/10.1007/s10551-005-5572-4

Ibrahim, N. A., Howard, D. P., \& Angelidis, J. P. (2009). The relationship between religiousness and corporate social responsibility orientation: Are there differences between business managers and students. Journal of Business Ethics, 78, 165-174. https://doi.org/10.1007/s10551-006-9321-0

Jamali, D., \& Mirshak, R. (2007). Corporate social responsibility: Theory and practice in a developing country. Journal of Business Ethics, 72, 243-262. https://doi.org/10.1007/s10551-006-9168-4

Jensen, M.C. (2002). Value maximization, stakeholder theory, and the corporate objective function. Business Ethics Quarterly, 12(2), 235-256. https://doi.org/10.2307/3857812

Jo, H., \& Harjoto, M. (2011). Corporate governance and firm value: The impact of corporate social responsibility. Journal of Business Ethics, 103(3), 351-383. https://doi.org/10.1007/s10551-011-0869-y

Jorge. M. L., \& and Peña, F. J. A. (2014). Determinants of corporate social responsibility and business ethics education in Spanish universities. Business Ethics: A European Review, 23(2), 139-153. https://doi.org/10.1111/beer.12041

Joyner, B. E., \& Payne, D. (2002). Evolution and implementation: A study of values, business ethics and corporate social responsibility. Journal of Business Ethics, 41, 297-311. https://doi.org/10.1007/s10551-008-9725-0

Kolodinsky, R. W., Madden, T.M., Zisk, D.S., \& Henkel, E.T. (2010). Attitudes about social responsibility: Business student predictors. Journal of Business Ethics, 91(2), 167-181. https://doi.org/10.1007/s10551-009-0075-3

Koljatic, M., \& Silva, M. (2015). Do business schools influence students' awareness of social issues? Evidence from two of Chili's leading MBA programs. Journal of Business Ethics, 131, 595-604. https://doi.org/10.1007/s10551-014-2295-4

Lam, (2014). Toward a harmonious society through corporate social responsibility. Journal of Public Affairs, 14(2), 105-115. https://doi.org/10.1002/pa.1515

Liu, Z., Yang, Z., Zeng, F., \& Waller, D. (2015). The Developmental Process of Unethical Consumer Behavior: An Investigation Grounded in China. Journal of Business Ethics, 128(2), 411-432. https://doi.org/10.1007/s10551-014-2061-7

Low, W., \& Davenport, E. (2006), Mainstreaming Fair Trade: Adoption, assimilation, appropriation. Journal of Strategic Marketing, 14(4), 315-327. https://doi.org/10.1080/09652540600947912

Lund-Thomsen, P., Lindgreen, A., \& Vanhamme, J. (2016). Industrial clusters and corporate social responsibility in developing countries: What we know, what we do not know, and what we need to know. Journal of Business Ethics, 133(1), 9-24. https://doi.org/10.1007/s10551-014-2372-8

MacFarlane, B., \& Ottewill, R. (2004). Business ethics in the curriculum: assessing the evidence from UK subject review. Journal of Business Ethics, 54(4), 339-347. https://doi.org/10.1007/s10551-004-1823-Z

Maclagan, P., \& Campbell, T. (2011). Focusing on individuals' ethical judgement in corporate social responsibility curricula. Business Ethics: A European Review, 20(4), 392-404. https://doi.org/10.1111/j.1467-8608.2011.01634.x

Mann, S. (2008). Analyzing Fair Trade in economic terms. Journal of Socio-Economics, 37, $2034-2042$. 
https://doi.org/10.1016/j.socec.2007.11.002

Matten, D., \& Moon, J. (2004). Corporate social responsibility education in Europe. Journal of Business Ethics, 54, 323-337. https://doi.org/10.1007/s10551-011-0742-z

Memon, Z. A., Bhutto, A., Chanar, Z. A., \& Robson, M. G. (2015). Finding corporate social responsibility research trends and content in Chinese universities: A literature review. International Journal of Technology Management \& Sustainable Development, 14 (3), 179-204. https://doi.org/10.1386/tmsd.14.3.179_1

Memon, Z. Z., Wei, Y. M., Robson, M. G., \& Khattak, M. A. O. (2014). Keeping track of corporate social responsibility as a business and management discipline: Case of Pakistan. Journal of Cleaner Production, 74, 27-34. https://doi.org/10.1016/j.jclepro.2014.03.057

Mohan, S. (2009). Fair Trade and corporate social responsibility. Economic Affairs, 29(4), 22-27. https://doi.org/10.1111/j.1468-0270.2009.01943.x

Moore, G., Slack, R., \& Gibbon, J. (2009). Criteria for responsible business practice in SMEs: An exploratory case of U.K. Fair Trade organizations. Journal of Business Ethics, 89, 173-188. https://doi.org/10.1007/s10551-008-9992-9

Muijen, H. S.C.A. (2004). Corporate social responsibility starts at university. Journal of Business Ethics, 53, 235-246. https://doi.org/10.1023/B:BUSI.0000039412.78194.1d

Murphy, P. E., \& Schlegelmilch, B. B. (2013). Corporate social responsibility and corporate social irresponsibility: Introduction to a special topic section. Journal of Business Research, 66(10), 1807-1813. https://doi.org/10.1016/j.jbusres.2013.02.001

Nicholls, A., \& Opal, C. (2005). Fair Trade: Market-driven ethical consumption. London: Sage Publications. https://doi.org/10.4135/9781446211526.n8

Ng, E.S., \& Burke, R. J. (2010). Predictor of business students' attitudes toward substantial business practices. Journal of Business Ethics, 95(4), 603-615. https://doi.org/10.1007/s10551-010-0442-0

Nicholson, C. Y., \& DeMoss, M. (2009). Teaching ethics and social responsibility: An evaluation of undergraduate business education at the discipline level. Journal of Education for Business, 213-218.

Özdemir, A. A., \& Sarikaya, M. (2009). An analysis of the curricula of business administration departments in Turkish universities with the perspective of civil society awareness. Journal of Education for Business, 84(5), 313-317. https://doi.org/10.3200/JOEB.84.5.313-317

Palihawadana, D., Oghazi, P., \& Liu, Y. (2016). Effects of ethical ideologies and perceptions of CSR on consumer behavior. Journal of Business Research, 69, 4964-4969. https://doi.org/10.1016/j.jbusres.2016.04.060

Paul, K., \& Hall, P. D. (1995). The influence of the JDR 3rd fund on business and society: Incorporating corporate social responsibility in the business curriculum. Journal of Business Ethics, 14, 769-779. https://doi.org/10.1007/BF00872330

Perneger, T., Courvoisier, D., Hudelson, P., \& Gayet-Ageron, A. (2015). Sample size for pre-tests of questionnaires. Quality Of Life Research, 24(1), 147-151. https://doi.org/10.1007/s11136-014-0752-2

Pham, D. H. (2011). Corporate social responsibility: A study on awareness of managers and consumers in Vietnam. Journal of Accounting and Taxation, 3(8), 162-170. https://doi.org/10.5897/JAT11.016

Randall, D. C. (2005). An exploration of opportunities for the growth of the Fair Trade market: Three cases of craft organizations. Journal of Business Ethics, 56, 55-67. https://doi.org/10.1007/s10551-004-1756-6

Ringov, D., \& Zollo, M. (2007). The impact of national culture on corporate social performance. Corporate Governance, 7(4), 476-485. https://doi.org/10.1108/14720700710820551

Rundle-Thiele, S. R., \& Wymer, W. (2010). A census of stand-alone ethics, social responsibility and sustainability course requirements for marketing graduates in Australia and New Zealand. Journal of Marketing Education, 32(1), 5-12. https://doi.org/10.1177 / 0273475309345002

Setó-Pamies, D., Domingo-Vernis, M., \& Rabassa-Figueras, N. (2011). Corporate social responsibility in management education: current status in Spanish universities. Journal of Management and Organization, 17(5), 604-620. https://doi.org/10.5172/jmo.2011.17.5.604

Shaw, D., \& Clarke, I. (1999). Belief formation in ethical consumer groups: an exploratory study. Marketing Intelligence and Planning, 17(2), 109-119. https://doi.org/10.1108/02634509910260968 
Smith, G. E. (2010). Filling the void: An exercise to enhance understanding of corporate social responsibility reporting using the global reporting indicative's G3 reporting guidelines. Proceedings of the Northeast Business \& Economics Association, 685-689. https://doi.org/10.22495/cocv7i4c1p5

Sohn, Y., Han, J., \& Lee, S. (2012). Communication strategies for enhancing perceived fit in the CSR sponsorship context. International Journal of Advertising, 31, 133-146. https://doi.org/10.2501/IJA-31-1-133-146

Su, S. H. (2006). Cultural differences in determining the ethical perception and decision making of future accounting professionals: a comparison between accounting students from Taiwan and the United States. Journal of American Academy Business, 9, 147-158. https://doi.org/10.1007/BF00381934

Sul, W., Choi, H. M., \& Quan, R. S. (2014). Shareholder conflict as a determinant of corporate social responsibility commitment for shared growth. Emerging Markets Finance \& Trade, 50(5), 97-110. https://doi.org/10.2753/REE1540-496X5001S107

Tari, J. J. (2011). Research into quality management and social responsibility, Journal of Business Ethics, 102, 626-638. https://doi.org/10.1007/s10551-011-0833-X

Taylor, P. L. (2005). In the market but not of it: Fair Trade coffee and Forest Stewardship Council Certification as $\begin{array}{llll}\text { market-based social change, World } & \text { 129-147. }\end{array}$ https://doi.org/10.1016/j.worlddev.2004.07.007

Tsakumis, G. T. (2007). The Influence of Culture on Accountants' Application of Financial Reporting Rules. ABACUS, 43, 27-49. https://doi.org/10.1111/j.1467-6281.2007.00216.x

Witkowski, T. H. (2005). Fair Trade marketing: an alternative system for globalization and development. Journal of Marketing Theory and Practice 13, 22-33. https://doi.org/10.1080/10696679.2005.11658556

Witkowski, T. H., \& Reddy, S. (2010). Antecedents of ethical consumption activities in Germany and the United States. Australasian Marketing Journal, 18, 8-14. https://doi.org/10.1016/j.ausmj.2009.10.011

Wong, A., Long, F., \& Elankumaran, S. (2010). Business students' perceptions of corporate social responsibility: The United States, China and India. Corporate Social Responsibility and Environmental Management, 17, 299-310. https://doi.org/10.1002/csr.216

Wood, E. (2007). What about me? Understanding the perspective of non-managerial employees in research on corporate citizenship. In den Hond, F., de Bakker, F. G. A. and Neergard, P. (Eds.), Managing Corporate Social Responsibility in Action (pp. 111-125). Aldershot: Ashgate. https://doi.org/10.4324/9781315593494

Yu, Y., \& Choi, Y. (2016). Stakeholder pressure and CSR adoption: The mediating role of organizational culture for Chinese companies. The Social Science Journal, 53, 226-235. https://doi.org/10.1016/j.soscij.2014.07.006

\section{Copyrights}

Copyright for this article is retained by the author(s), with first publication rights granted to the journal.

This is an open-access article distributed under the terms and conditions of the Creative Commons Attribution license (http://creativecommons.org/licenses/by/4.0/). 